\title{
ОСОБЛИВОСТІ ОПИСУ ТЕМПОРАЛЬНОЇ СТРУКТУРИ ПУБЛІЦИСТИЧНИХ ТЕКСТІВ
}

Талаш I. О. Особливості опису темпоральної структури публіцистичних текстів.

У статті проаналізовані логіко-філософські погляди на поняття «час»; визначені екстралінгвістичні чинники, що впливають на організацію темпоральної структури текстів публіцистичного стилю.

Ключові слова: час, темпоральність, темпоральна структура тексту, публіцистичний стиль.

Талаш И. А. Особенности описания темпоральной структуры публицистических текстов.

В статье проанализированы логико-философские взгляды на понятие «время»: определены экстралингвистические факторы, влияющие на организацию темпоральной структуры текстов публицистического стиля.

Ключевые слова: время, темпоральность, темпоральная структура текста, публицистический стиль.

Talash I. O. Particularly of description temporal structure of publicistic texts.

The article analyzes logical and philosophic view of idea «time»; defined extralinguistic condition, which influence at the organization of temporal structure texts of publicistic style.

Key words: time, temporal, temporal structure texts, publicistic style.

Сучасний етап розвитку функціональної стилістики характеризується переходом від статистичного опису специфічних для певної групи текстів мовних засобів, що відбираються 3 системи мови за принципами цільового призначення й частотності вживання, до виявлення їх мовленнєвої системності. У центрі уваги знаходяться проблеми впливу екстралінгвістичних чинників на мовленнєву систему стилю, а також 3'ясування закономірностей функціонування мови в різних типізованих сферах спілкування.

Однією 3 найважливіших сфер сучасної суспільно-виробничої діяльності $\epsilon$ масова комунікація, про що, зокрема, свідчить активний розвиток жанрово-стильових різновидів текстів, через які власне й реалізується спілкування. Провідним стилем у цій сфері є публіцистичний, основне призначення якого - служити розв'язанню суспільно-політичних питань, активно впливати на читачів, переконувати у справедливості певної ідеї, спонукати їх до творчої діяльності, пропагувати прогресивні ідеї, учення, знання, здоровий спосіб життя [11, с. 272]. Публіцистичне мовлення має впливати на переконання, поведінку читацької аудиторії, на оцінку фактів, подій, формувати громадську думку. Реалізація цих завдань зумовлює мобільність публіцистичного стилю, високий рівень чутливості до найменших змін у системі мовлення. 
Загальноприйнятим $є$ твердження про те, що кожен функціональний стиль мовлення, зокрема й публіцистичний, має характерну темпоральну організацію, яка може бути представлена у вигляді функціональносемантичного поля (далі - ФСП) темпоральності. У мовознавстві є низка досліджень, у яких науковці намагаються проаналізувати темпоральну структуру тексту, з'ясувати співвідношення текстового, рецептивного й реального часів. Т. Матвєєва відзначає складність темпоральної структури тексту, у якій реальний час поєднується з часом перцептивним, пов'язаним зі сприйняттям реальної дійсності $[10$, с. 30$]$. Г. Золотова також робить акцент на складності текстового часу й нетотожності його відповідній граматичній категорії. Дослідниця звертає увагу на те, що темпоральна сфера тексту формується автором, створеним ним текстом і відображеним у тексті світом [6]. Складність аналізу темпоральної структури публіцистичних текстів зумовлена також неоднозначним тлумаченням серед науковців самого поняття «реальний час».

Мета нашої статті - узагальнити різні підходи до логікофілософського тлумачення поняття «час» та визначити екстралінгвістичні чинники, що впливають на темпоральну організацію публіцистичних текстів.

Логіко-філософське осмислення поняття «час» подане в працях М. Ахундова, А. Гулідова і Ю. Наберухіна, М. Дяченка і О. Частника, В. Жданова, С. Лазарєва, В. Ольховського, К. Сімакова, Я. Стратій, С. Черепанова, Б. Юркова.

Більшість лінгвістичних досліджень присвячені висвітленню функціональних можливостей окремих компонентів ФСП темпоральності (С. Єрмоленко, Г. Золотова, Г. Їжакевич і В. Кононенко, С. Соколова i Н. Шумарова, 3. Тураєва, Д. Шмельов та інших), й обмаль праць спрямовані на з'ясування особливостей часової організації текстів певного функціонального типу (Ю. Арешенков, А. Баранов, О. Бондар, Т. Матвєєва, О. Москальська, О. Реферовська та інші).

Мовностилістичні й комунікативно-прагматичні особливості публіцистичного мовлення досліджувалися в працях Д. Баранника, А. Васильєвої, І. Гамрецького, А. Гвоздєва, В. Грицини, С. Срмоленко, М. Жовтобрюха, Є. Журбіної, Н. Іпполітової, О. Китиці, П. Коваленко, Л. Майданової, Л. Мацько, О. Пономарева, Г. Соганика та інших. Характеристика жанрової системи публіцистичного стилю висвітлена в працях Ю. Арешенкова, І. Арнольд, С. Равлюк, М. Фелера та інших.

В історії розвитку уявлень про час можна виокремити три основні напрямки: міфологічні уявлення; фізикалістичні уявлення нового часу; розвиток ідеї часу в теорії А. Енштейна та В. Вернадського.

Прадавні уявлення про час беруть початок у міфологічній свідомості, коли людина усвідомлює неповторність власного «Я», яке ідентифікує себе як дещо відмінне від оточуючого середовища і разом із тим як елемент цієї різноманітності. Саме тоді людина намагається структурувати 
довкілля, знайти відповіді на питання про першопричину існування Всесвіту й себе в ньому. Більшість дослідників фольклору відзначає, що «...можна, очевидно, говорити про міфопоетичну модель пульсуючого простору, поєднану 3 циклічно-лінійною моделлю часу» [4, с. 74] як універсальну для уявлень давньої людини. Про це свідчить, зокрема, наявність календарної обрядовості в різних етносів, яка безпосередньо пов'язана 3 циклічністю протікання процесів у природі. Разом із тим, як справедливо зауважують науковці, будь-яка культура виробляє власну концепцію часу.

Розвиток природничих наук у період XVII - XVIII століть, відкриття у фізиці, зроблені I. Ньютоном, що органічно пов'язані з уявленнями давніх греків про час як міру руху, дають поштовх до активного дослідження об'єктивних закономірностей природи, вивчення не самого часу, а руху, зміни речей, тобто протікання матеріальних процесів у часі. Ці концептуальні положення дозволяють увести в науковий обіг поняття «стріли часу» і виокремити такі його характеристики, як-от: спрямованість (вектор часу спрямований з минулого в майбутнє), лінійність (наступність подій у часі), однорідність, незмінність, наявність абсолютного (астрономічного) й профанічного часу.

Із розвитком теорії відносності А. Енштейна, час почав розглядатися через призму особливості розподілу руху матерії в просторі, при цьому зазначалося, що різним видам рухової матерії відповідають якісно різні форми простору-часу. Час почав нерозривно пов'язуватися з простором.

Розвиваючи свою концепцію біосфери, В. Вернадський поряд із виявленням інваріантів у різних незворотних процесах постійно підкреслював специфічне для кожного з них виявлення часу. Це дозволило йому вперше в науковій і філософській літературі ввести поняття «різні типи часу» - фізичний, геохімічний, біологічний, геологічний, психофізичний, історичний, космічний. Науковець наполягав на тому, що в світі не існує зворотних процесів, а ілюзія зворотності, яку можна спостерігати на прикладі хімічних процесів, $є$ виявленням симетричних систем. Адже речовина, повернена у вихідний стан, не $є$ абсолютно тотожною тій, яка вступила в реакцію. Ці інваріанті, універсальні якості будь-яких незворотних процесів дозволили В.Вернадському емпірично встановити такі якості реального часу: незворотність (односпрямованість), беззначність (оскільки час не має вектора спрямування, то він завжди збільшується і ніколи не зменшується), анізотропність (неоднорідність, що зумовлено особливостями відкритих систем, здатних до саморозвитку).

На сучасному етапі розвитку науки більшість науковців схиляється до концепції часу, поданій у працях $\mathrm{B}$. Вернадського, справедливо зазначаючи, що оскільки час не $є$ предметом нашого сприйняття, то поки що не існує об'єктивних способів і засобів, щоб його виміряти. Однак є дослідники, які дотримуються фізикалістичного підходу до пояснення часу 
як «іманентно властива системі структура її процесу» [9, с. 82]. Відповідно, суттєвими ознаками часу називають циклічність (ієрархічність) i спрямованість, наголошуючи на тому, що циклічність можна використати для створення «метрики часу».

На нашу думку, найбільш об'єктивними є положення, що обгрунтовуються в працях прибічників концепції В. Вернадського. Адже очевидним є той факт, що, з одного боку, час - феномен, який людина не здатна осягнути, а з іншого, - кожен має суб'єктивне відчуття часу. Як справедливо зауважує В. Жданов, «час як даність завжди переживається людиною, і в цьому сенсі він суб'єктивний... Переживання часу - це глибоко внутрішнє переживання. Воно базується на певному сприйнятті... може бути визначене як відчуття часу» [5, с. 153].

Часові відношення реальної дійсності передаються вербально за допомогою так званих темпоральних висловлювань, які можна виокремити за чіткою ознакою - потенційна локалізованість у часі. Указівка на часовий інтервал у темпоральних висловлюваннях відображає форму мислення, тому завжди містить ознаки суб’єктивності. На цьому наголошує, зокрема Г. Золотова, визначаючи темпоральну структуру тексту як співвідношення трьох часових планів - реального часу, який існує поза текстом; подієвого часу, що являє собою таксисний зв’язок усіх предикатів тексту в плані одночасності / послідовності, передування / слідування; перцептивного часу - просторово-темпоральної позиції автора тексту [6, с. 15].

Детермінованість часової структури тексту авторською позицією вимагає при описі його темпоральної структури враховувати історикополітичні й етнічно-культурні умови, у яких він створювався. Як зазначає С. Черепанов, «відповіді на питання про те, як і чому в нас виникають ті чи ті уявлення про реальність, треба шукати в особливостях антропосоціогенеза, моделюючи загальний перебіг еволюції, пов'язаний 3 виникненням абстрактного мислення й предметним освоєнням дійсності» [15, с. 26]. Так, зміна релігійних чи політичних формацій тягне за собою поступову зміну відчуття часу народом. У дохристиянський період сприйняття часу давніми було циклічним, про це свідчать, зокрема, міфи та легенди, а також ранні літописи, у яких час вимірювався «літами», тобто від одного літа до іншого. Поступово, після прийняття християнства, часовий цикл розгортається в лінію, і все частіше починають у писемних пам'ятках вести обчислення часу «від різдва Христового». Ці тенденції підсилюються формуванням у добу Середньовіччя другого виміру (який радикально відрізнявся від хліборобського, органічно пов'язаного з циклічним усвідомленням часу) українського етнонаціонального образу - козацтва. Це спричинило, як зазначає В. Кафарський, суттєву деформацію українського етнотипу [7, с. 319] і підсилило відчуття часу як процесу лінійного й незворотного.

В. Жданов, досліджуючи проблему часу в давньоєгипетському світі, також звертає увагу на зміну відчуття часу, що зумовлена зміною 
політичних формацій [5]. У зв'язку з цим дослідники говорять про спрямованість соціальної спільноти в минуле (архаїзація суспільства, оберненість у минуле, пошана традицій i, як наслідок, консерватизм) чи спрямованість у майбутнє (захопленість науково-технічним прогресом, віра в краще майбутнє, творче переосмислення традицій).

Низка досліджень присвячена обгрунтуванню залежності відчуття часу від суспільно-економічних формацій. Зокрема, Я. Стратій пов'язує формування усвідомлення часу як лінійного й незворотного процесу не 3 історико-політичними чинниками, а зі зміною способу соціальноекономічних відносин людей у суспільстві - розвиток і поступове ускладнення товаровиробництва й торгівлі. У суспільстві більшого значення надають індивідуальним здібностям, талановитості, зростає усвідомлення унікальності кожної особистості. За таких умов людина спрямовує зусилля на осягнення сенсу буття, прагне максимально використати свої здібності, через збагачення культури свого народу уникнути забуття. Суттєвою ознакою нового темпорального мислення було усвідомлення історичних дистанцій, що спричинило намагання вивільнитися від позачасового підходу до осмислення культури. Особливості відчуття часу соціумом і пов'язані з цим настрої не залежно від причини їх виникнення мобільно фіксують публіцистичні тексти в силу своєї стильової специфіки.

Неповторність системи мови взагалі і способів вираження часу зокрема зумовлюють також етнічні особливості світосприйняття, освоєння дійсності. Оскільки, як уже зазначалося, темпоральна структура висловлювання зумовлена формою мислення, а вона у свою чергу формується в процесі етногенезу, то відмінності семантико-граматичного вираження часових відношень будуть, очевидно, позначені національною специфікою. Наприклад, традиційне вимірювання часу за місячним (переважно східні етноси) чи солярним календарем, а також співвідношення семантичних відтінків темпоральності й лексико-граматичних способів їх вираження.

Варто зазначити, що формування етнічної спільноти також відбувається під впливом певних факторів, а саме: історичні умови; культурні фактори; природно-кліматичні фактори (зумовлюють характер провідної діяльності нації, що впливає на формування матеріальної й духовної культури нації, особливості їі економічних зв'язків з іншими націями); соціально-політичні фактори; економічні фактори [2, с. 56-64].

Аналіз і зіставлення логіко-філософських підходів до розуміння поняття «час» i факторів розвитку етнічної спільноти дають змогу стверджувати, що в основу переважної більшості філософських концепцій часу покладено один із факторів формування етнічної спільноти. Разом із тим етнологи й етнопсихологи одностайні у твердженні про те, що серед названих факторів формування етнічної спільноти жоден не може бути визначений як домінантний, адже всі вони, з одного боку, самодостатні, а 3 
іншого, - взаємозалежні. 3 огляду на те, що формування відчуття часу відбувається паралельно з процесами етногенезу, на нашу думку, аналіз темпоральної структури публіцистичного тексту повинен бути спрямований передусім на виявлення специфіки відчуття часу соціумом у певний історичний період і відбуватися, відповідно, з урахуванням комплексу екстралінгвістичних чинників, що могли впливати на цю структуру.

Таким чином, під час опису темпоральної структури тексту необхідно враховувати не лише семантико-граматичні способи вираження часових відношень, а й зважати на історико-політичні й етнокультурні чинники, що впливають на формування системи мови. За таких умов опис темпоральної структури публіцистичних текстів може виявити актуальний стан розвитку мови, означити перспективи, а також діагностувати психоемоційний стан етнічної спільноти.

\section{Література}

1. Ахундов М.Д. Концепция пространства и времени: истоки, эволюция, перспективы / Мурад Давидович Ахундов. - М. : Наука, 1982. - 221 с.

2. Баронин А. С. Этнопсихология : [учеб. пос.] / Анатолий Станиславович Баронин. - К. : МАУП, 2000. - 116 с.

3. Гулидов А. И. Существует ли «стрела времени»? / А. И. Гулидов, Ю. И. Наберухин // Философия науки. - 2003. - №2 (17). - С. 3-15.

4. Дяченко М. Простір і час фольклорних світів : пам'ять генерацій / М. Дяченко, О.Частник // Філософська думка. - 1999. - №1-2. - С.64-79.

5. Жданов В. В. Проблемы времени в древнеегипетской мысли / В. В. Жданов // Вопр. философии. - 2003. - №2. - С. 152-160.

6. Золотова Г. А. Категория времени и вида с точки зрения текста / Г. А. Золотова // Вопр. языкознания. - 2002. - №3. - С. 8-29.

7. Кафарський В. І. Етнологія : [підручн.] / В.І. Кафарський, Б. П. Савчук. - К. : Центр навчальної літератури, 2006. - 432 с.

8. Кохан Я. Часова тривалість 3 логічної точки зору / Я. Кохан // Філософська думка. - 2001. - №3. - С. 3-16.

9. Лазарев С. С. Понятие «время» и геологическая летопись земной коры / С. С. Лазарев // Вопр. философии. - 2002. - №1. - С. 77-89.

10. Матвеева Т. В. Функциональные стили в аспекте текстовых категорий: Синхронно-сопоставительный очерк / Т. В. Матвеева. - Свердловск : Изд-во Урал. ун-та, 1990. - $172 \mathrm{c}$.

11. Мацько Л. І. Стилістика української мови : [підручн.] / Мацько Л. І., Сидоренко О. М., Мацько О. М. - К. : Вища шк., 2003. - 462 с.

12. Ольховський В. С. Простір і час / В. С. Ольховський // Пульсар. - 2001. № 8. - C. 2-5.

13. Симаков К. В. Концепция реального времени-дления В. И. Вернадского / К. В. Симаков // Вопр. философии. - 2003. - №4. - С. 88-101.

14. Стратий Я. М. Проблемы натур-философии в философской мысли Украины XVII в. : [монография] / Ярослава Михайловна Стратий. - К. : Наукова думка, 1981. - 207c.

15. Черепанов С. К. К вопросу о номологическом обосновании стрелы времени / С. К. Черепанов // Философия науки. - 2000. - №1 (7). - С. $22-28$.

Стаття надійшла до редакиії 23.09.2010 p. 